\title{
ZNAČAJ EKONOMSKE RAZVIJENOSTI DRŽAVE ZA UVOĐENJE OBRAČUNSKE RAČUNOVODSTVENE OSNOVICE U JAVNOM SEKTORU
}

Ivan Milojević, Nikola Milanović i Milan Mihajlović Univerzitet odbrane u Beogradu, Vojna akademija

$\mathrm{M}_{\mathrm{s} i}^{\mathrm{o}}$ ogućnost uvođenja obračunske osnove u budžetskom računovodstvu Republike Srbije može se dovesti u vezu sa iskustvima država koje su ga već implementirale. Ovaj rad je usmeren na analizu odnosa između ekonomskog razvoja države i implementacije računovodstvenih instrumenata koji podržavaju obračunsku osnovu, posebno uzimajući u obzir prilagođavanje postojećih računovodstvenih sistema potrebama obračunskog računovodstvenog modela usled ekonomskog razvoja.

Svetska tendencija je da sve veći broj zemalja prelazi na obračunsko računovodstvo. Danas veliki broj svetskih ekonomskih institucija i organizacija, kao što su Svetska banka, Međunarodni monetarni fond, Međunarodna federacija računovođa, Evropska unija, itd., postali su pristalice obračunskog računovodstva i uključile su se u podržavanju ostalih zemalja da implementiraju obračunsku osnovu u svom budžetskom računovodstvu.

Ključne reči: računovodstvena osnovica, budžetski sistem, razvijenost država

Uvod

Dojavom novog javnog menadžmenta dolazi do velikih promena, među kojima je i uvođenje obračunske računovodstvene osnove u budžetskom računovodstvu. Prve zemlje koje su implementirale obračunsko računovodstvo u svom javnom sektoru su države anglosaksonskog pravnog sistema u kojima su se pokazale značajne prednosti. Ove prednosti su se odnosile na obezbeđivanje kvalitetnijih informacija, u smislu da državni menadžment sada može imati komforniji uvid u elemente koji prikazuju finansijsku poziciju države, upravljati njenim obavezama, planirati rashode i prihode kako na kratkoročnom, tako i na dugoročnom planu.

Uvođenje obračunskog računovodstva utiče i na povećanje transparentnosti upravljanja javnim sredstvima, što omogućava poreskim obveznicima uvid u načine trošenja sopstvenog novca. Obračunska računovodstvena osnovica danas posmatrano zamenila je gotovinsku, koje je u prethodnom periodu bila dominantna u svetu. Razlozi prelaska leže u efikasnosti iskaznih pozicija finansijskih izveštaja. U okviru ovog rada prikazaćemo uzročnoposledične veze između uvođenja obračunske osnovice i stepena razvijenosti država. 


\section{Pretpostavke i metode analize}

Zastupljenost osnovica koje koriste računovodstveni sistemi država u svetu potrebno je posmatrati prema segmentima u zavisnosti od stepena razvijenosti i to za potrebe našeg istraživanja grupa razvijenih i grupa zemalja u razvoju.

U ovom radu koristimo korelacionu analizu za određivanje statusa odnosa i strukture stepena razvijenosti država i pojedinačnih vrsta osnovica koje koriste računovodstveni sistemi javnog sektora pojedinih država.

Rast bruto domaćeg proizvoda (BDP-a) je glavni dinamički pokazatelj napretka jedne nacionalne ekonomije. (Aureo, 2016) Međutim, potreba se javlja i za pokazateljima koji će označiti čitav socioekonomski razvoj jedne ekonomije, jer nivo socioekonomske razvijenosti utiče na sam proces implementacije, njegovu dužinu i visinu troškova. Indeks koji prikazuje socioekonomsku razvijenost zemlje je „IDI“ indeks. Pored BDP-a, „IDI“ indeks predstavlja najpribližniju ocenu razvoja jedne zemlje.

U radu su korišćeni podaci Svetskog ekonomskog foruma kao i Međunarodne asocijacije računovođa IFAC.

Tokom istraživanja primenili smo model koeficijenta korelacije Pearson $r_{x y}=C_{x y} / S_{x}$ $\mathrm{SD}_{\mathrm{u}} \cdot$ Gde $\mathrm{C}_{\mathrm{xy}}$ označava kovarijansu i $\mathrm{SD}_{\mathrm{x}} \cdot \mathrm{SD}_{\mathrm{u}}$ standardne devijacije proizvoda $\mathrm{h}$ i y. (Joe, Suzanne, Delphine, 2016)

Da bismo u narednom periodu izvršili vrednovanje u skladu sa ekonomskim kretanjima, koristili smo metod linearnog vremenskog trenda $y=b_{0}+b_{1} x$, gde je $Y$ linearna funkcija $b_{0}$ (prosek) i $b_{1}$ (srednji apsolutni prirast) koji predstavljaju parametre, a h predstavlja vremensku promenljivu. Za izračunavanje procena parametara trenda korišten je metod najmanjih kvadrata.

\section{Analiza zastupljenosti obračunskog računovodstva}

$\mathrm{Na}$ osnovu podataka možemo videti relativni udeo računovodstvenih osnova u zemljama sveta, koje su podeljene u dve grupe: razvijene zemlje i zemlje u razvoju, a posebno su prikazane i zemlje Evropske Unije.

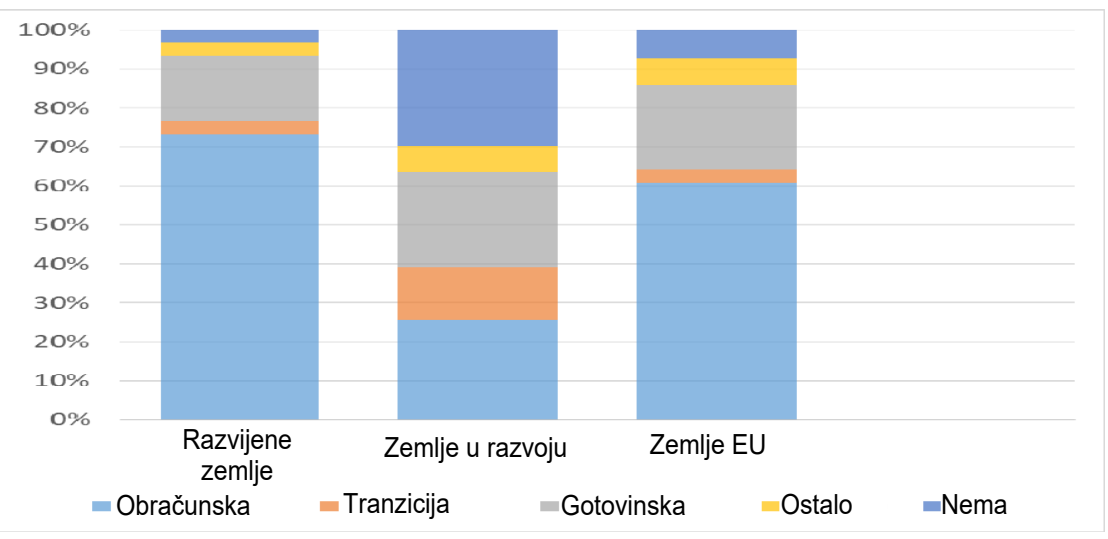

Grafik 1 - Procentualni udeo računovodstvenih osnova u svetu 
U trećem stubu, kod zemalja Evropske unije (EU), možemo videti da $60 \%$ članica EU primenjuju obračunsko računovodstvo, što je takođe dokaz da EU ohrabruje zemlje članice, a naročito zemlje kandidate za članstvo, da reformišu svoj budžetski sistem i implementiraju obračunsko računovodstvo. (Lazić, 2018)

Iz prikazanog možemo zaključiti da preko $65 \%$ najrazvijenijih zemalja sveta primenjuje obračunsko računovodstvo, a da je kod zemalja u razvoju, procenat zastupljenosti obračunskog računovodstva iznosi oko $25 \%$.

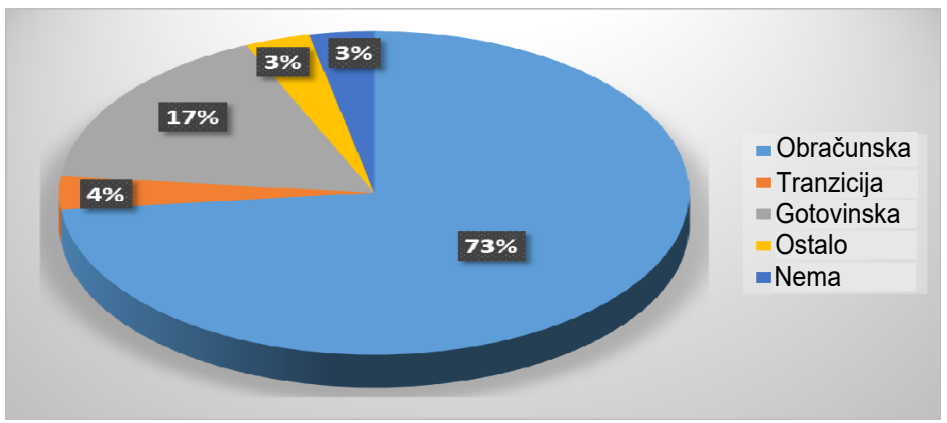

Grafik 2 - Prisustvo obračunske osnove u razvijenim zemljama sveta

Razvijene zemlje imaju veliko učešće obračunske osnovice u svom računovodstvenom sistemu, na šta upućuje analiza da $73 \%$ razvijenih zemalja primenjuje obračunsku osnovu, a samo $4 \%$ razvijenih zemalja je trenutno u procesu tranzicije ka obračunskom računovodstvu, $17 \%$ razvijenih zemalja primenjuje gotovinsku osnovu u svom budžetskom računovodstvu i samo 3\% zemalja primenjuje neku od modifikovanih osnova. (Milojević, 2017)

Kada ovih $4 \%$ zemalja završi proces tranzicije i pređe na obračunsko računovodstvo, onda se može reći da čak $3 / 4$ najrazvijenijih zemalja primenjuje obračunsko računovodstvo. Ovim primećujemo da obračunsko računovodstvo u potpunosti dominira kod razvijenih zemalja, a što nam govori da društveno-ekonomski sistemi razvijenih zemalja pogoduju primeni obračunske osnovice, na šta moraju biti spremne i zemlje u razvoju.

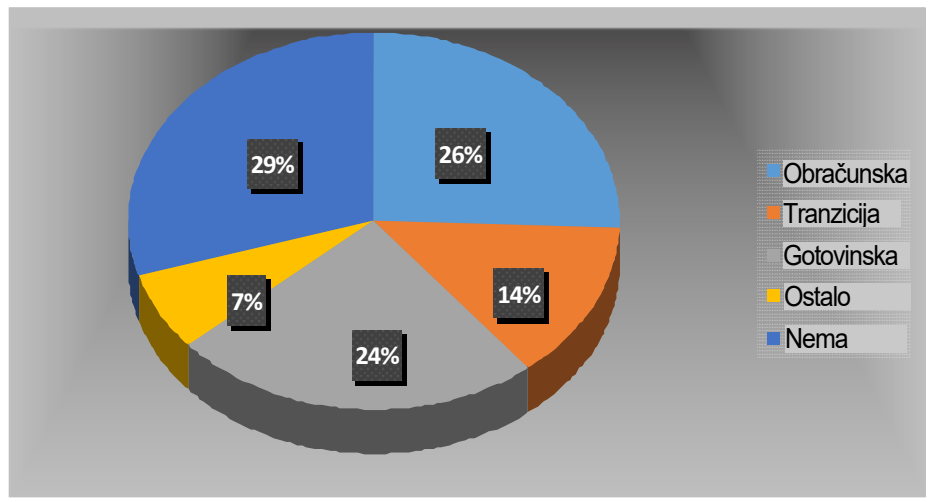

Grafik 3 - Učešće obračunske osnove kod zemalja u razvoju 
Kod zemalja u razvoju imamo izmenjenu sliku korišćenja računovodstvene osnove u javnom sektoru. Analizom smo došli do rezultata da $26 \%$ zemalja u razvoju primenjuje obračunsku osnovu, $13 \%$ zemalja je trenutno u procesu tranzicije ka obračunskom računovodstvu, $24 \%$ zemalja primenjuje gotovinsku osnovu u svom budžetskom računovodstvu, $7 \%$ zemalja primenjuje neku od modifikovanih osnova i kod $30 \%$ zemalja u razvoju nije poznat sistem koji one primenjuju.

Na prvi pogled primećuje se, ako zanemarimo procenat zemalja za koje nemamo podatke, da je udeo zemalja u razvoju koje primenjuju obračunsku i gotovinsku osnovu gotovo izjednačeno. (Steger, 2013) Tom podatku takođe trebamo dodati i 13\% zemalja u razvoju koje su u procesu tranzicije ka obračunskom računovodstvu. Kada ove zemlje, koje se u procesu tranzicije, pređu na obračunsko računovodstvo, može se zaključiti da će tada obračunsko računovodstvo postati dominantno i kod zemalja u razvoju, i to sa $39 \%$ u odnosu na $24 \%$ koje bi predstavljalo zemlje koje koriste gotovinsko računovodstvo, a što možemo videti na grafiku 4.

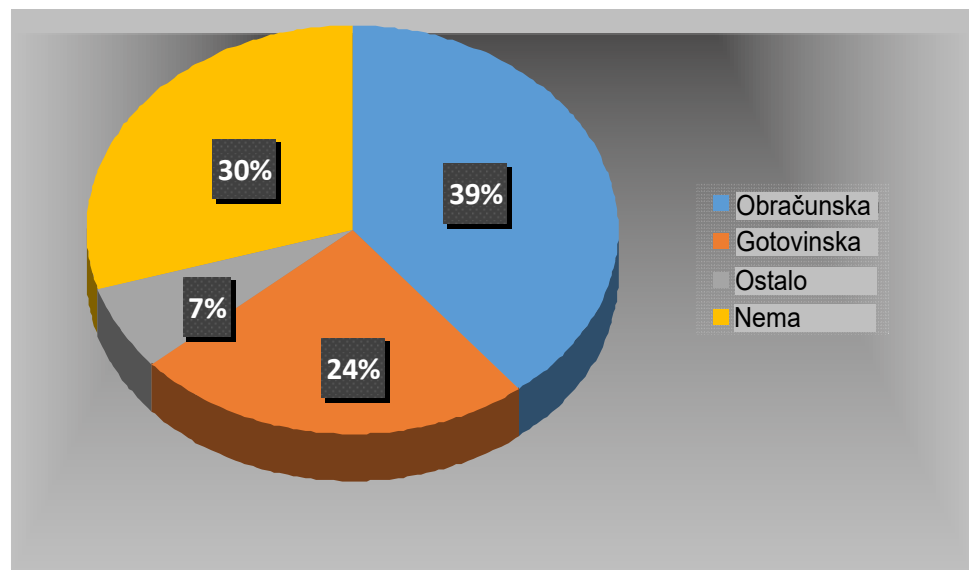

Grafik 4 - Prisustvo obračunske osnove kod zemalja u razvoju nakon tranzicije

$\mathrm{Na}$ osnovu svih prikazanih podataka zaključujemo da obračunsko računovodstvo dominira kod razvijenih zemalja, ali da će vremenom takođe zauzeti dominantno mesto i kod zemalja u razvoju.

\section{Analiza odnosa razvoja zemalja i računovodstvene osnovice javnog sektora}

Tendencija prelaska sa gotovinske na obračunsku osnovicu u budžetskom računovodstvu datira iz osamdesetih godina 20. veka. Takođe, poznato je i to da su obračunsku osnovu u budžetskom računovodstvu primenile zemlje koje se veoma razlikuju po pitanju socio-ekonomske razvijenosti, ali se sam period implementacije obračunske osnove razlikovao od zemlje do zemlje. (Otrusinova, Pastuszkova, 2013) U okviru ovih odnosa postavlja se značajno pitanje kako ekonomski razvoj zemalja utiče na proces implementacije ob- 
računske osnovice u računovodstvenom sistemu javnog sektora države, odnosno da li sama socio-ekonomska razvijenost zemlje utiče na vremenski period koji je potreban da bi se implementirala obračunska osnova u budžetskom računovodstvu određene zemlje.

Za uzorak su uzete države sa pokazateljem socio-ekonomske razvijenosti (Prelić, Nešić, Gajić, 2018) kao i period implementacije obračunske osnovice u računovodstvo javnog sektora odabranih država koji su prikazani u narednoj tabeli.

Tabela 1 - „IDI“ indeks i dužina implementacije obračunskog računovodstva nekih zemalja sveta

\begin{tabular}{|c|l|c|c|}
\hline R. br. & \multicolumn{1}{|c|}{ Države } & IDI indeks & $\begin{array}{c}\text { Period implementacije } \\
\text { (u godinama) }\end{array}$ \\
\hline 1. & Island & 6.07 & 3 \\
\hline 3. & Australija & 5.36 & 3 \\
\hline 4. & Austrija & 5.36 & 4 \\
\hline 5. & Novi Zeland & 5.35 & 3 \\
\hline 6. & Ceška republika & 5.25 & 4 \\
\hline 7. & Kanada & 5.09 & 11 \\
\hline 8. & Francuska & 5.05 & 5 \\
\hline 9. & Ujedinjeno Kraljevstvo & 4.89 & 11 \\
\hline 10. & Japan & 4.53 & 6 \\
\hline 11. & Peru & 4.29 & 10 \\
\hline
\end{tabular}

Izvor: http://www3.weforum.org/docs/WEF_Forum_IncGrwth_2018.pdf

Na osnovu podataka IDI indeksa i perioda implementacije, koje se nalaze tabeli, izračunat je koeficijent korelacije koji iznosi - 0,64, na osnovu koga možemo zaključiti da su ove dve promenljive, tj. indeks socio-ekonomske razvijenosti zemlje i period implementacije obračunskog računovodstva, inverzno zavisne. (Živić, Lovrić, Pavličić, 1995)

To znači da vremenski period koji je potreban za implementaciju obračunske osnove u budžetskom računovodstvu veoma zavisi od socio-ekonomske razvijenosti zemlje.

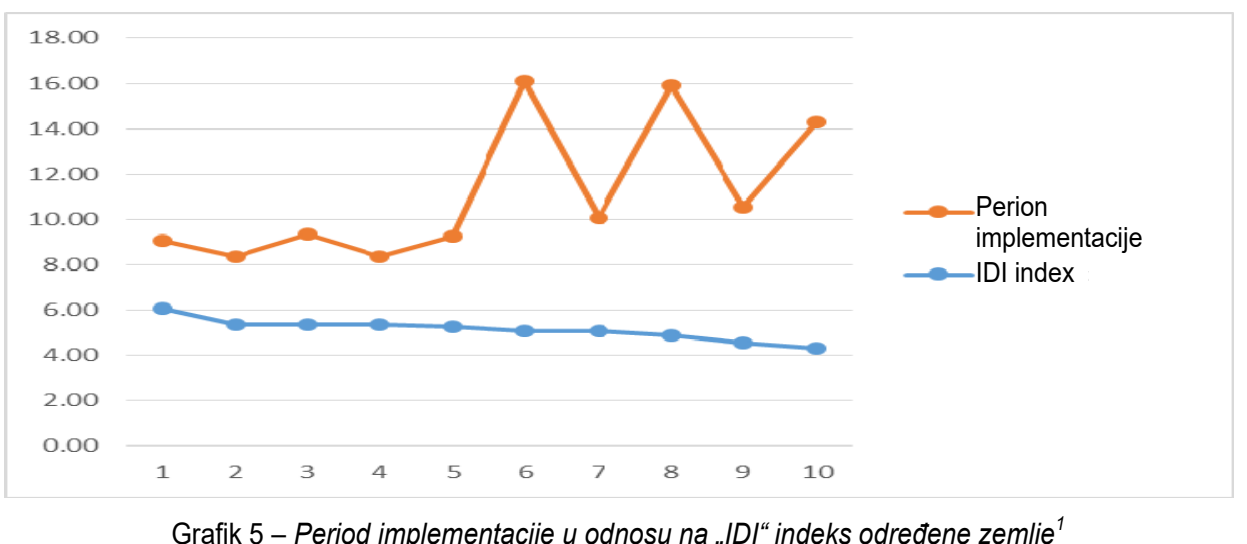

\footnotetext{
${ }^{1} \mathrm{Na} x$ osi prikazane su zemlje iz tabele 3 , označene brojevima, a na y osi nalaze se vrednosti koje označavaju visinu socio-ekonomskog razvoja i potreban broj godina za implementaciju obračunskog računovodstva.
} 
Vojnoekonomski pregled

Trend analizom došli smo do rezultata da se period implementacije obračunske osnovice kao računovodstvene osnovice javnog sektora kod razvijenih zemalja ima tendenciju skraćenja. Na ovaj način nameće se zaključak da se socio-ekonomski razvoj zemalja jedna od komponenti koja utiče na brzinu implementacije obračunske osnovice.

\section{Zaključak}

$\mathrm{Na}$ osnovu svega prikazanog možemo zaključiti da odnos procesa implementacije obračunske osnove u budžetskom računovodstvu i ekonomske snage pojedinih država ima inverznu korelacionu vezu. Nakon definisanja odabrane populacije na kojoj je izvršeno istraživanje računovodstvene osnove, prikazani su odnosi odabranih zemalja sveta u korišćenju različitih računovodstvenih osnova, a takođe i zemalja koje su u procesu prelaska sa gotovinskog na obračunsko računovodstvo. Zatim je analizirana zastupljenost računovodstvenih osnova u svetu i niihova analiza.

Rezultati istraživanja pružaju potrebna saznanja o računovodstvenim obračunskim sistemima koji se koriste u svetu i kod nas, a na osnovu kojih je izvršena međusobna komparacija i ispunjen cilj ovog istraživanja. Dobijena saznanja se pre svega odnose na uvođenje i evoluciju računovodstvenih osnovica koja se koristi u javnom sektoru država u svetu, elemente tranzicije i njihove periode implementacije.

Model tranzicije sa gotovinskog računovodstva na obračunsko računovodstvo u javnom sektoru posmatranih država jasno upućuje na predstojeće mogućnosti budžetskog računovodstvenog sistema Republike Srbije da se prilagodi obračunskom modelu budžetskog računovodstva uvažavajući vrednosti ekonomskog razvoja, uz poštovanje svih načela finansijskog izveštavanje i međunarodnih računovodstvenih standarda za javni sektor.

\section{Literatura}

[1] Aureo, B. (2016). Razvoj računovodstva. Oditor - časopis za Menadžment, finansije i pravo, 2(3), 39-48.

[2] Joe C., Suzanne F., Delphine M. (2016), Implementing Accrual Accounting in the Public Sector, Fiscal Affairs Department, International Monetary Fund.

[3] Lazić, S. (2018). Bilansiranje finansijske imovine budžetskih korisnika. Oditor - časopis za Menadžment, finansije i pravo, 4(1), 6-16.

[4] Milojević I. (2017), Fiskalna konsolidacija računovodstvenog sistema budžeta, Centar za ekonomska istraživanja, Beograd.

[5] Otrusinova M., Pastuszkova E. (2013), Transformation Process of State Accounting to Accrual Basis Accounting in Conditions of the Czech Republic, Universitatis Agriculturae et Silviculturae Mendelianae Brunensis.

[6] Prelić, J., Nešić, B., \& Gajić, T. (2018). Računovodstvene asocijacije evropskog područja. Oditor - časopis za Menadžment, finansije i pravo, 4(1), 119-129.

[7] Steger G. (2013), Budget reform in Austria. From traditional to modern budgeting, Instituto de Estudios Fiscales.

[8] http://www.ifac.org/news-events/2018-11/65-governments-globally-will-report-accrual-basis2023-finds-new-report

[9] http://www3.weforum.org/docs/WEF_Forum_IncGrwth_2018.pdf

[10] World Economic Forum, The Inclusive Development Index 2018: Summary and Data Highlights, Switzerland.

[11] Živić. M, Lovrić M, Pavličić D.(1995), Metodi statističke analize, Univerzitet u Beogradu, 1995. 